\title{
IPTEKS PENGHITUNGAN SIKLUS HIDUP PERUSAHAAN (STUDI KASUS PADA PERUSAHAAN TERBUKA DI BURSA EFEK INDONESIA)
}

\author{
Irene Florensia Pontoh ${ }^{1}$ \\ ${ }^{1}$ Program Studi Akuntansi, Fakultas Ilmu Sosial dan Hukum, Universitas Prisma, Jl. Pomorow No. 113 \\ Kelurahan Tikala Baru Kecamatan Tikala, Manado, 95126, Indonesia \\ E-mail : irenepontoh5@gmail.com
}

\begin{abstract}
Rapid growth of economics makes many firms continue to develop their business. Along with the rapid growth of business the high competition rising between firms in term to snatch the market or consumers. The higher of competition gives an impact to firms life cycle which makes many firms keep develop their business strategy to attract the investors and consumers. Under assumption that the median is 0.76 based on sample, the result of calculation of the retained earnings to total equity (RETE) in period of 2016 shows that life cycle of each firms are varies. The result shows that firms under median are not at mature stage while firms above median are categorized as mature firms.
\end{abstract}

Keywords : firm life cycle, maturity, contributed earned mix, RETE

\section{PENDAHULUAN}

Perkembangan ekonomi global membuat banyak perusahaan terus mengembangkan bisnis yang dikelolanya. Seiring dengan berkembangnya bisnis tersebut maka tingkat persaingan antar perusahaan terutama perusahaan yang bergerak dalam segmen pasar yang sama menjadi semakin tinggi. Tingkat persaingan yang semakin tinggi memberikan pengaruh yang cukup signifikan pada kondisi keuangan perusahaan sehingga berdampak pada siklus hidup bagi perusahaan tersebut. Siklus hidup perusahaan merupakan indikator bagi investor dalam melakukan investasi di dalam sebuah perusahaan sehingga hal ini membuat perusahaan berusaha menciptakan strategi sesuai dengan perkembangan siklus hidupnya.

Menurut Lynch (2006), secara alami strategi korporasi akan berubah seiring dengan perubahan industry atau bisnisnya dengan mengikuti siklus hidupnya. Lynch (2006) menjelaskan bahwa siklus hidup sebuah perusahaan memiliki beberapa tahap, yaitu : (1) tahap pengenalan industri (introductory), dimana dalam tahap ini perusahaan berusaha menciptakan daya tarik produknya; (2) tahap pertumbuhan (growth), dimana dalam tahap ini para pesaing mulai memperhatikan pergerakan bisnis perusahaan sehingga menimbulkan dampak persaingan; (3) tahap kematangan (maturity), dimana dalam tahap ini perusahaan telah memiliki kepercayaan konsumen atas produk yang dipasarkan; dan (4) tahap penurunan (decline), dimana pada tahap ini timbul sebuah kondisi bahwa beberapa pesaing mulai muncul dan berhasil mengimbangi perusahaan yang telah ada dan dapat memungkinkan terjadinya penurunan tingkat penjualan dari perusahaan tersebut.

\section{TINJAUAN PUSTAKA}

Hill dan Jones (2009) menjelaskan bahwa siklus hidup perusahaan dapat terdiri 4 (empat) tahap, yaitu : (1) tahap embrio, merupakan tahap dimana perusahaan tersebut lahir; (2) tahap pertumbuhan, merupakan tahap dimana perusahaan mulai melakukan penetrasi ke dalam sebuah pasar; (3) tahap transisi, merupakan tahap dimana terdapat konsumen baru yang datang atau pergi; (4) tahap kematangan, merupakan tahap dimana perusahaan telah mapan dan tidak akan mengalami pertumbuhan; dan (5) tahap penurunan, merupakan tahap dimana perusahaan mulai kehilangan pasar yang cenderung disebabkan oleh perubahan 
teknologi, perubahan sosial, perubahan demografi, dan persaingan internasional. Hasan dan Cheung (2018) menemukan bahwa sebuah perusahaan yang memiliki investasi yang lebih besar akan memiliki lebih banyak peluang untuk mencapai tahap kematangan (maturity). Garengo, Nudurupati, dan Bititci (2007), dan O'Connor dan Byrne (2015) menyatakan bahwa perusahaan yang telah mencapai kematangan pada umumnya dapat mengidentifikasi kebutuhan organisasinya melalui sistem pengukuran kinerja dan sistem informasi manajemen dari perusahaan itu sendiri.

Budiarso dan Pontoh (2016) menemukan bahwa perusahaan yang telah mencapai tingkat kematangan cenderung memiliki utang yang rendah akan tetapi memiliki profitabilitas yang cukup baik. Fama dan French (2001), Grullon et al. (2002), dan Budiarso et al. (2019) menemukan bahwa pada umumnya perusahaan yang telah mencapai tingkat kematangan cenderung membayar dividen lebih besar, memiliki ukuran perusahaan yang besar, memiliki profitabilitas yang baik, memiliki jumlah dana bebas yang besar, dan kurang memiliki peluang investasi. DeAngelo et al. (2006), Denis dan Osobov (2008), dan Fairchild et al. (2014) menunjukkan bahwa salah satu indikator untuk menghitung siklus hidup sebuah perusahaan dapat menggunakan rasio Retained Earnings to Total Equity (RETE).

\section{METODE DAN TEKNIK PENERAPAN IPTEKS}

\subsection{Metode Penerapan Ipteks}

Penerapan ipteks akan menggunakan analisis rasio Retained Earnings to Total Equity (RETE), dimana dalam rasio ini akan memberikan hasil yang merupakan indikator kematangan sebuah perusahaan. Penerapan ipteks menggunakan sampel 13 perusahaan yang terdaftar di Bursa Efek Indonesia dalam periode 2016.

\subsection{Teknik Penerapan Ipteks}

Teknik atas penerapan ipteks adalah sebagai berikut :

(a) menentukan laba bersih perusahaan untuk setiap periode;

(b) menentukan saldo laba/laba ditahan perusahaan untuk setiap periode; dan

(c) menentukan rasio retained earnings to total equity perusahaan untuk periode 2016.

\section{PEMBAHASAN}

\subsection{Gambaran Objek Penerapan Ipteks}

Akasha Wira International Tbk. (ADES) didirikan pada tanggal 06 Maret 1985. Saat ini Akasha Wira International Tbk. (ADES) bergerak di bidang industri barang konsumen. Fast Food Indonesia Tbk. (FAST) didirikan pada tanggal 19 Juni 1978. Saat ini Fast Food Indonesia Tbk. (FAST) bergerak di bidang industri dagang, jasa, dan investasi. Sumi Indo Kabel Tbk. (IKBI) didirikan pada tanggal 23 Juli 1981. Saat ini Sumi Indo Kabel Tbk. (IKBI) bergerak di bidang industri lainnya. Indo-Rama Synthetics Tbk. (INDR) didirikan pada tanggal 03 April 1974. Saat ini Indo-Rama Synthetics Tbk. (INDR) bergerak di bidang industri lainnya. Indika Energy Tbk. (INDY) didirikan pada tanggal 19 Oktober 2000. Saat ini Indika Energy Tbk. (INDY) bergerak di bidang industri pertambangan. Resource Alam Indonesia Tbk. (KKGI) didirikan pada tanggal 08 Juli 1981. Saat ini Resource Alam Indonesia Tbk. (KKGI) bergerak di bidang industri pertambangan. Lionmesh Prima Tbk. (LMSH) didirikan pada tanggal 14 Desember 1982. Saat ini Lionmesh Prima Tbk. (LMSH) bergerak di bidang industri dasar dan kimia. Mustika Ratu Tbk. (MRAT) didirikan pada tanggal 14 Maret 1978. Saat ini Mustika Ratu Tbk. (MRAT) bergerak di bidang industri barang konsumen. Bukit Asam Tbk. (PTBA) didirikan pada tanggal 02 Maret 1981. Saat ini Bukit Asam Tbk. (PTBA) bergerak di bidang industri pertambangan. Surya Citra Media Tbk. (SCMA) didirikan pada tanggal 29 Januari 1999. Saat ini Surya Citra Media Tbk. (SCMA) bergerak di bidang industri dagang, jasa, dan investasi. Ultra Jaya Milk Industry \& Trading Company Tbk. (ULTJ) didirikan pada tanggal 02 November 1971. Saat ini Ultra Jaya Milk 
Industry \& Trading Company Tbk. (ULTJ) bergerak di bidang industri barang konsumen. Unggul Indah Cahaya Tbk. (UNIC) didirikan pada tanggal 07 Februari 1983. Saat ini Unggul Indah Cahaya Tbk. (UNIC) bergerak di bidang industri dasar dan kimia. Voksel Electric Tbk. (VOKS) didirikan pada tanggal 19 April 1971. Saat ini Voksel Electric Tbk. (VOKS) bergerak di bidang industri lainnya.

\subsection{Pembahasan}

Berdasarkan data yang dipublikasikan oleh Bursa Efek Indonesia, maka diperoleh data saldo laba, dan total ekuitas seperti yang disajikan pada Tabel 1. Pada Tabel 1 juga disajikan hasil penghitungan rasio Retained Earnings to Total Equity (RETE) sebagai indikator siklus hidup sebuah perusahaan. Adapun formula yang digunakan dalam menghitung rasio Retained Earnings to Total Equity (RETE) adalah :

$$
\text { Retained Earnings to Total Equity }(\mathrm{RETE})=\frac{\text { Saldo Laba }}{\text { Total Ekuitas }}
$$

Tabel 1. Penghitungan RETE

\begin{tabular}{crrc}
\hline Kode Perusahaan & Saldo Laba & Total Ekuitas & RETE \\
\hline ADES & 640,731 & 384,388 & 1.67 \\
FAST & $10,022,753$ & $1,223,211$ & 8.19 \\
IKBI & 160,633 & 845,014 & 0.19 \\
INDR & $1,799,957$ & $4,021,357$ & 0.45 \\
INDY & $2,886,729$ & $9,957,548$ & 0.29 \\
KKGI & $1,383,604$ & $1,134,544$ & 1.22 \\
LMSH & 107,552 & 117,316 & 0.92 \\
MRAT & 235,556 & 369,089 & 0.64 \\
PTBA & $11,365,741$ & $10,552,405$ & 1.08 \\
SCMA & $23,753,808$ & $3,705,408$ & 6.41 \\
ULTJ & $2,847,117$ & $3,489,233$ & 0.82 \\
UNIC & $1,191,753$ & $2,165,726$ & 0.55 \\
VOKS & 249,867 & 669,044 & 0.37 \\
\hline
\end{tabular}

Sumber : data olah, 2019

Hasil penghitungan rasio Retained Earnings to Total Equity (RETE) menunjukkan bahwa siklus hidup perusahaan-perusahaan yang terdaftar dalam Bursa Efek Indonesia pada periode tahun 2016 adalah sangat bervariasi. Jika diasumsikan bahwa median dihitung berdasarkan pada sampel data pada Tabel 1, maka titik median yang ditentukan adalah sebesar 0.76. Berdasarkan median yang telah ditentukan maka dapat disimpulkan bahwa status perusahaan-perusahaan yang berada diatas median (0.76) berada pada tahap matang jika ditinjau dari sudut pandang keuangan, sedangkan status perusahaan-perusahaan yang berada dibawah median adalah belum matang. Tabel 2 menyajikan status perusahaanperusahaan sampel dalam penerapan ipteks ini. 


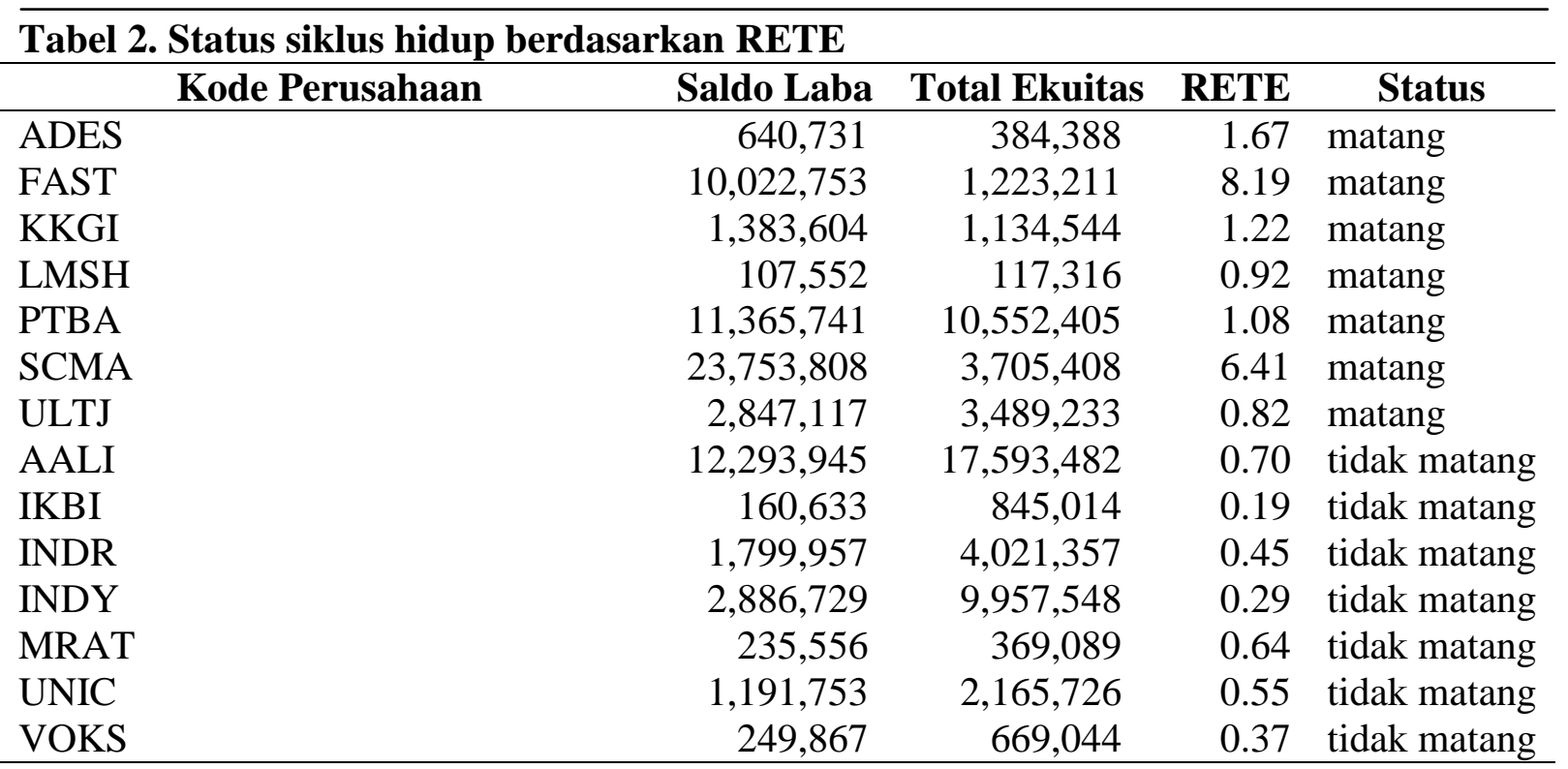

Sumber : data olah, 2019

\section{KESIMPULAN DAN SARAN}

\subsection{Kesimpulan}

Penghitungan rasio Retained Earnings to Total Equity (RETE) menunjukkan siklus hidup sebuah perusahaan. Berdasarkan hasil penghitungan rasio Retained Earnings to Total Equity (RETE) maka investor dapat melakukan penyusunan portfolio investasi guna menyusun kombinasi investasi yang kemungkinan dapat memberikan kemungkinan keuntungan optimal. Hal ini disebabkan karena perusahaan yang berada pada tahap matang dapat memberikan tingkat pengembalian yang diharapkan dari investor yang dapat berupa dividen atau dapat memberikan keuntungan selisih harga saham (capital gain).

\subsection{Saran}

Berdasarkan hasil penghitungan rasio Retained Earnings to Total Equity (RETE) maka diharapkan rasio ini dapat memberikan referensi bagi investor dalam melakukan investasi. Bagi masyarakat akademik, khususnya yang berada pada bidang akuntansi dan keuangan dapat menjadikan rasio ini sebagai variabel dalam topik kajian pasar modal, misalnya dalam topik kajian kebijakan dividen dari sebuah perusahaan.

\section{DAFTAR PUSTAKA}

Budiarso, N. S., \& Pontoh, W. (2016). Firm's dividend decision in Indonesia: Cater or mature?. Journal of Life Economics, 3(3), 53-66. https://doi.org/10.15637/jlecon.139

Budiarso, N. S., Subroto, B., Sutrisno, \& Pontoh, W. (2019). Dividend catering, life-cycle, and policy : Evidence from Indonesia. Cogent Economics \& Finance, 7(1), 1-15. https://doi.org/10.1080/23322039.2019.1594505

DeAngelo, H., DeAngelo, L., \&Stulz, R. M. (2006). Dividend policy and the earned/contributed capital mix: A test of the life-cycle theory. Journal of Financial Economics, 81(2), 227-254. https://doi.org/10.1016/j.jfineco.2005.07.005

Denis, D. J., \& Osobov, I. (2008). Why do firms pay dividends? International evidence on the determinants of dividend policy. Journal of Financial Economics, 89(1), 62-82. https://doi.org/10.1016/j.jfineco.2007.06.006 
Fairchild, R., Guney, Y., \& Thanatawee, Y. (2014). Corporate dividend policy in Thailand: Theory and evidence.International Review of Financial Analysis, 31, 129-151. doi:10.1016/j.irfa.2013.10.006

Fama, E. F., \& French, K. R. (2001). Disappearing dividends: changing firm characteristics or lower propensity to pay? Journal of Financial Economics, 60(1), 3-43. https://doi.org/10.1016/S0304-405X(01)00038-1

Garengo, P., Nudurupati, S., \& Bititci, U. (2007). Understanding the relationship between PMS and MIS in SMEs: An organizational life-cycle perspective. Computers in Industry, 58(7), 677-686. https://doi.org/10.1016/j.compind.2007.05.006

Grullon, G., Michaely, R., \& Swaminathan, B. (2002). Are dividend changes a sign of firm maturity? The Journal of Business, 75(3), 387-424. http://dx.doi.org/10.1086/339889

Hasan, M. M., \& Cheung, A. (2018). Organization capital and firm life cycle. Journal of Corporate Finance, 48, 556-578. https://doi.org/10.1016/j.jcorpfin.2017.12.003

Hill, C. W. L., \& Jones, G. R. (2009). Essentials of Strategic Management, $2^{\text {nd }}$ Edition. Mason,South-Western, Cengage Learning

Lynch, R. (2006). Corporate strategy, $4^{\text {th }}$ Edition. England : Pearson Education Limited

O'Connor, T. \& Byrne, J. (2015). Governance and the corporate life-cycle. International Journal of Managerial Finance, 11(1), 23-43. http://dx.doi.org/10.1108/IJMF-032013-0033 